\title{
Real Wages and the Business Cycle: Accounting for Worker and Firm Heterogeneity *
}

\author{
Anabela Carneiro, Paulo Guimarães, and Pedro Portugal
}

May 2008

\begin{abstract}
Using a longitudinal matched employer-employee data set for Portugal over the 1986-2005 period, this study analyzes the heterogeneity in wages responses to aggregate labor market conditions for newly hired workers and existing workers. Controlling simultaneously for worker and firm specific effects, the results show that entry wages are much more procyclical than current wages. A one-point increase in the unemployment rate decreases wages of newly hired male workers by around $2.5 \%$ and by just $1.5 \%$ for workers in continuing jobs. For female workers these same effects are $2.3 \%$ and $1.1 \%$, respectively. Thus, our empirical evidence does not seem to lend support to the hypothesis of wage stickiness as an explanation for the unemployment volatility puzzle.

JEL classification: D21; E24; E32; J31

Keywords: wage cyclicality; hires; fim-specific effects
\end{abstract}

${ }^{*}$ We thank Lucena Vieira for excellent computational assistance and Fundação para a Ciência e Tecnologia for financial support (research grant POCTI/ECO/35147/99). The data used in this article are confidential but the authors' access is not exclusive. 


\section{Introduction}

The cyclical behavior of real wages has been the subject of a large number of studies since the debate of Keynes (1939), Dunlop (1938), and Tarshis (1939). Earlier studies based on aggregate data showed some ambiguous results. In this case, the best conclusion is that the choice of the time period analysis, price deflator, and cyclical indicator, as well as the choice between wage rates and average earnings (including overtime or not), may substantially affect the estimates of real wage cyclicality [Abraham and Haltiwanger (1995)]. One reason why these studies have reached no definitive conclusions resides in the fact that they have been performed at the aggregate level. In particular, they have ignored the changes in the composition of the workforce over the cycle. The presence of compositional effects has attracted much attention in the last years and recent microdata studies based on panel data for the U.S. showed that composition bias plays an important role on real wage behavior along the business cycle [see, for example, Mitchell et al. (1985), Bils (1985), Keane et al. (1988) and Solon et al. (1994)]. In fact, cyclical changes in the composition of the work force may induce a countercyclical bias in the aggregate real wage. Aggregate measures of real wages tend to give more weight to low-skill workers during expansions than during recessions. The argument is that if less-skilled workers are more vulnerable to layoff, they will account for a smaller share of employment in recessions than in expansions. An additional general problem of aggregation is that it assumes that the relationship between real wages and the business cycle is the same for all individuals or groups of individuals. If wrong, the estimates of real wage cyclicality include a specification bias.

Over the last two decades, a number of studies based on micro-panel data for the U.S. (and recently for Britain) found, without exception, robust evidence in favor of a procyclical behavior of real wages. ${ }^{1}$ Panel microdata also shows that real wage changes of job movers are much more procyclical than real wage changes of job stayers [see Solon et al. (1994), Shin (1994) and Devereux (2001) for the U.S. and Devereux and Hart (2006) and Hart (2006) for Britain].

Several theoretical explanations have been advanced in order to explain why job changers have more procyclical wages. The more frequent explanation relies on the existence of interindustry wage differentials. This interpretation was first advanced by Okun (1973), who argued that certain jobs offer rents to workers. If these sectors are also more cyclically sensitive, workers can switch into high-paying jobs during booms because such jobs are less tightly rationed during these times.

Beaudry and DiNardo (1991) advanced a more convincing explanation for the differences in wage cyclicality between job stayers and job changers, even though their explanation abstracts from heterogeneity across jobs. According to their findings, current unemployment rate does not affect wages after controlling for the best labor market conditions, since a worker was hired at his/her current job. Indeed, when workers are not mobile between employers, current labor market conditions do not affect current wages. In this case, current wages are negatively correlated with the unemployment rate at the time each worker was hired. However, if workers are very mobile, wages are correlated with the best labor market conditions observed since the worker was hired.

Barlevy (2001) offered a new explanation for the existence of more procyclical wages of job changers: compensating differentials. In order to show that compensating differentials instead of interindustry wage differentials generate a more procyclical behavior of wages of changers, Barlevy developed a model that relates unemployment insurance and wage cyclicality. His empirical finding of a negative relationship between wage cyclicality among job changers and the level of unemployment insurance benefits, supports the view that job changers' wages are more procyclical because

\footnotetext{
${ }^{1}$ For insightful surveys see Brandolini (1995) and Abraham and Haltiwanger (1995).
} 
in booms they obtained jobs that pay a compensating differential for the risk of layoff. In this case, workers who change jobs during booms may not realize true gains from the higher wages they receive, since these gains are typically offset during recessions.

Recent microeconometric evidence on wage cyclicality also gave a new insight to the discussion about business cycle fluctuations of unemployment and vacancies and wage stickiness. Indeed, some authors argue that the Mortensen-Pissarides [Mortensen and Pissarides (1994) and Pissarides (2000)] search and matching model cannot explain the cyclical volatility of unemployment and vacancies [Hall (2003) and Shimer (2005)]. Furthermore, they also show that if the hypothesis of rigid wages is introduced the model performs much better to match fluctuations in unemployment and vacancies [see Hall (2005) and Shimer (2004)].

In a recent exercise, however, Pissarides (2007) showed that the wage stickiness hypothesis does not seem to match the empirical data. Exploring the idea that in the search and matching model job creation is driven by the difference between the expected productivity and the expected cost of labor in new matches, Pissarides shows that in equilibrium the wages negotiated in new matches are about as cyclical as productivity. This prediction of the model seems to be consistent with the empirical evidence that wages in new matches are much more procyclical than wages in continuing jobs.

Haefker et al. (2007) also defend this point of view. Using the CPS they showed that wages of newly hired workers are much more volatile than aggregate wages and respond one-to-one to changes in labor productivity.

In this context, the challenge to empirical research is to have appropriate data that allow to test if wages in new matches are more volatile than those in continuing jobs. As mentioned before, previous empirical studies have been showing that job changers' wages are much more procyclical than job stayers' wages. However, and since these studies do not seem to control for compositional effects, it can always be argued that this empirical evidence merely reflects the impact on wages of workers drifting from low wage firms to high wage firms in expansions, and vice-versa for recessions.

Relative to the empirical literature on wage cyclicality, this paper's main contribution is to analyse the impact of the cycle on real wage growth of new hires versus stayers within the same firm. The key question to be answered is: are starting-wages, conditional, say, on the long-term wage policy of the firm, more sensitive to the economic cycle? To our knowledge, this is the first study that explicitly deals with this issue taking simultaneously into account for worker and firm unobserved heterogeneity. For this purpose a unique and rich matched employer-employee data set - Quadros de Pessoal - will be used in order to test if, controlling for unobserved firm specific effects, entry wages are much more procyclical than current wages. Quadros de Pessoal is an annual mandatory employment survey collected by the Portuguese Ministry of Employment. It covers all establishments with wage earners. Reported data cover the establishment itself, the firm and each of its workers. Since unique identifiers are available for both firms and workers, firms and individuals can be tracked over the sample period. Currently, the data set collects data on about 340,000 firms and 3 million employees.

Two additional contibutes of this paper deserve attention. The first is to test if the impact of the unemployment rate on wages really reflects labor-market tightness disentangling between the job finding probability and the job separation probability. Finally, in this study the behavior of bargained wages and the wage cushion over the cycle is also analyzed.

This study will be organized as follows. Section 2 presents the architecture of the Portuguese wage setting system. In Section 3 the data set and methodology are described. The main results and some robustness checks are discussed in Section 4. Conclusions are outlined in Section 5. 


\section{The Architecture of the Portuguese Wage Setting System}

\subsection{Collective Bargaining}

The Portuguese Constitution provides the juridical principles of collective bargaining and grants unions the right to negotiate. The effects of the agreements are formally recognized and considered valid sources of labor law.

Concerning the bargaining mechanisms, a distinction should be made between the conventional regime and the mandatory regime. Conventional bargaining results from direct negotiation between employers' and workers' representatives. A mandatory regime, on the other hand, does not result from direct bargaining between workers and employers, being instead dictated by the Ministry of Labor. The Ministry can extend an existing collective agreement to other workers initially not covered by it or it can create a new one, if it is not viable to extend the application of an existing document. A mandatory regime is applied when workers are not covered by unions, when one of the parties involved refuses to negotiate or bargaining is obstructed in any other way. ${ }^{2}$ Therefore, the impact of collective bargaining goes far beyond union membership and the distinction between unionized and non-unionized workers or firms becomes meaningless.

Usually, collective negotiations are conducted at the industry or occupation level. Firm-level negotiation, which for a time was a common practice in large public enterprises, has lost importance. The law does not establish mechanisms of coordination between agreements reached in different negotiations; however preference is given to vertical over horizontal agreements, and the principle of the most favorable condition to the worker generally applies.

Since most collective agreements are industry-wide, covering companies with very different sizes and economic conditions, their contents tend to be general, setting minimum working conditions, in particular the base monthly wage for each category of workers, overtime pay and the normal duration of work. Moreover, only a narrow set of topics is updated annually, and therefore the content of collective agreements is often pointed out as being too immobile and containing little innovation.

Whatever the wage floor agreed upon for each category of workers at the collective bargaining table, firms are free to pay higher wages, and they often deviate from that benchmark, adjusting to firm-specific conditions [see Aperta et al. (1994) and Portugal and Cardoso (2005)].

The Portuguese system of industrial relations apparently presents features of a centralized wage bargaining system. Indeed, massive collective agreements, often covering a whole industry, predominate in the economy, while firm-level collective bargaining covers a low proportion (less than $10 \%$ ) of the workforce. Moreover, trade union confederations, employers' federations and the Government meet at the national level each year to set a guideline for wage increases (the so-called "social concertation"). However, this guideline is not mandatory and merely guides the collective bargaining that follows. The Council for Social Concertation, latter replaced by the Social and Economic Council, was created in 1984 as a tripartite forum (government, workers and employers' representatives) with the aim of promoting "social concertation", but its role concerning income and wage policies remains limited.

\footnotetext{
${ }^{2}$ Beyond the existence of compulsive extension mechanisms, voluntary extensions are also possible, when one economic partner (workers' representative or employer) decides to subscribe to an agreement which it had initially not signed.
} 
On the other side, the fragmented nature of the trade union structure, the fragmented employers' associations and the multiplicity of bargaining units provides the system with a certain degree of decentralization. Even though collective bargaining in Portugal takes place at a sectoral level and most workers are covered by the bargaining system due to the existence of mandatory extensions, the coordination between bargaining units is rather limited. In fact, the right to negotiate is given upon every employer or employers' association and to every trade union (regardless of the number of affiliated members they represent), and the parties have the possibility of choosing the level of negotiation - regional, occupational, industrial or national. This leads to the existence of a diffuse and complex system of wage bargaining with negotiation fragmented and agreements multiplied.

\subsubsection{Minimum Wages}

A mandatory minimum monthly wage was set for the first time in Portugal in 1974, covering workers aged 20 or older and excluding agriculture and domestic servants. Currently, there is a unique legal minimum wage that applies to all workers. Workers formally classified as apprentices receive just $80 \%$ of the full rate.

The minimum wage is updated annually by the parliament, under government proposal. ${ }^{3}$ Decisions on the level of the minimum wage are taken on a discretionary basis, usually taking into account past and predicted inflation and after consulting the social partners.

In 2005 , the minimum monthly wage level was $374.7 €$, representing $40 \%$ of the average monthly wage in the private sector. In this same year the proportion of workers that received the minimum legal wage was about $5 \% .^{4}$

\footnotetext{
${ }^{3}$ The only exceptions are 1982, when it was not updated, and 1989, when it was updated twice.

${ }^{4}$ Source: Department of Statistics (GEP) - Ministry of Labor and Social Security.
} 


\section{Data and Methodology}

\subsection{Data Description}

The data source of this study comes from a unique and rich matched employer-employee data set - Quadros de Pessoal $(Q P)$. $Q P$ is an annual mandatory employment survey collected by the Portuguese Ministry of Labor and Social Security, that covers virtually all establishments with wage earners. ${ }^{5}$ Indeed, each year every establishment with wage earners is legally obliged to fill in a standardized questionnaire. Reported data cover the establishment itself (location, industry and employment), the firm (location, industry, employment, sales, ownership, and legal setting) and each of its workers (gender, age, education, skill, occupation, admission date, earnings, and duration of work). The information on earnings is very complete. It includes the base wage (gross pay for normal hours of work), regular benefits, irregular benefits and overtime pay, as well as the mechanism of wage bargaining. Information on normal and overtime hours of work is also available.

Eighteen spells of $Q P$, from 1986 to 2005, were available for this study. ${ }^{6}$ From 1986 to 1993 the information was collected in March of each year, and since 1994, in October.

There are three main reasons that make this survey a good source for the study of wage cyclicality. The first is its coverage. By law, the questionnaire is made available to every worker in a public space of the establishment. This requirement facilitates the work of the services of the Ministry of Labor that monitor compliance of firms with the law (e. g., illegal work). Indeed, the administrative nature of the data and its public availability implies a high degree of coverage and reliability. Over the 1986-2005 period, the data set covers, on average, 200,000 firms and 2.5 million workers per year. Second, this survey is conducted on a yearly basis, and its identifying scheme allows accurate identification of firms and workers making it possible to track them over the years. Each firm entering the database is assigned a unique identifying number and the Ministry implements several checks to ensure that a firm that has already reported to the database is not assigned a different identification number. Using this identifier it is possible to pinpoint all firms that have entered and exited economic activity. The workers' identification number is based on a transformation of his/her social security number. We match the individuals over the years based on their identification number, gender, year and month of birth. Finally, this source enables the matching of firms and its workers, which allows us to classify the situation of the worker on the job (stayer/mover, accession/separation). Moreover, employer-reported wage information is known to be subject to less measurement error than worker-reported data.

Our data set includes the population of full-time wage earners in the private non-farm sector, aged between 20 and 55 years old. ${ }^{7}$ We have also excluded those individuals for whom some explanatory variable is not available for a particular year, namely those with no information on wages and hours worked. In order to minimize the effects of outliers in wages, we dropped $1 \%$ of the observations corresponding to the top and bottom tails of the wage distribution.

In order to control for workers' unobserved heterogeneity using the first-differences estimation method, most empirical studies of real wage cyclicality tend to restrict the sample to workers employed for two consecutive years. In this study this restriction is avoided in order to be able to include in the analysis those individuals with a weak labor force/employment attachment. Thus, our data set includes the individuals that are present in two consecutive years (hereinafter 'two-year

\footnotetext{
${ }^{5}$ Public administration and non-market services are excluded.

${ }^{6}$ No computer files are available for the years 1990 and 2001.

${ }^{7}$ In agriculture a considerable amount of payments are non-pecuniary. We thought it better to exclude these workers from the analysis. In any case, the number of these workers is almost negligible.
} 
employee'), ${ }^{8}$ but also contains those individuals that are present in the $Q P$ registers in year $t$ but are absent in year $t+1$ (hereinafter 'separations'). ${ }^{9}$ It also includes the newly hired workers, the so-called 'accessions'. A worker is classified in period $t$ as newly hired if his tenure in that year is less or equal to 12 months. In this context, a newly hired worker may refer to an individual that moved between firms or to an individual that comes from non-employment.

Two-year employee may also be classified as 'stayers' or 'movers'. A 'job stayer' is identified as a worker that was employed within the same firm for two consecutive years. A 'job mover' is defined as a worker that moved to a different firm from period $t-1$ to period $t$.

The male population includes 14.315,913 year $\times$ individuals observations corresponding to around 4 million individuals matched by identifying number and date of birth. According to Table 1, male job stayers are numerically the most important group corresponding to 10.882,692 observations. Furthermore, $1.203,119$ observations refer to movers, $3.445,218$ to separations and $2.410,850$ to new hires. The female sample contains $9.398,893$ year $\times$ individuals observations corresponding to around 2.9 million individuals. Female stayers correspond to $7.005,185$ observations, movers to 672,821 , separations to $2.415,541$ and accessions to $1.695,451$ observations. It should be noted that, in a given year, an individual may be classified simultaneously as an accession and separation or, for example, as a mover and a new hire. Thus, the sum of the observations in each of the four groups does not correspond to the total number of observations.

Table 1: Data Set Composition

\begin{tabular}{lcr}
\hline \hline & Males & \multicolumn{1}{c}{ Females } \\
\cline { 2 - 3 } Stayers & $10.882,682$ & $7.005,185$ \\
Movers & $1.203,119$ & 672,821 \\
Accessions & $2.410,850$ & $1.606,385$ \\
Separations & $3.445,218$ & $2.415,541$ \\
\hline \hline
\end{tabular}

Tables A.1.1 and A.1.2 of Appendix A describes the data for male and female workers, respectively.

\subsection{Empirical Methodology}

The empirical model that will be used to test for real wage cyclicality is a classic human-capital wage equation with a control for business cycle conditions. The static form of the model is:

$$
\begin{array}{r}
W_{i t}=\alpha+\gamma_{1} t+\gamma_{2} t^{2}+\gamma_{3} C Y C_{t-1}+\gamma_{4} Z_{i}+\gamma_{5} X_{i t}+\gamma_{6} X_{i t}^{2}+\varepsilon_{i t}, \\
i=1, \ldots, N ; \quad t=1, \ldots, T
\end{array}
$$

where $W_{i t}$ is the natural $\log$ of the real wage of individual $i$ in time $t, C Y C_{t-1}$ is a cyclical indicator such as the aggregate unemployment rate, ${ }^{10} t$ and $t^{2}$ are a time trend and its square, $X_{i t}$ is a vector

\footnotetext{
${ }^{8}$ It should be noted that when a worker is present in the $Q P$ files for more than one time in a given year, the register in the firm in which he had worked a higher number of hours was selected.

${ }^{9}$ Hence, separations are only identified between 1986 and 2004.

${ }^{10}$ Since wages are set at least six months to one year in advance, there is a delayed relationship between wages and economic growth. To capture this lagged effect we use the unemployment rate of the previous year.
} 
of time-varying worker characteristics such as experience and its square $\left(X_{i t}^{2}\right), Z_{i}$ is a vector of time-invariant worker characteristics such as education and $\varepsilon_{i t}$ is a zero-mean random term with constant variance.

If the cyclical indicator corresponds to the unemployment rate, the parameter $\gamma_{3}$ measures the percent wage change in response to a one-point increase in the unemployment rate. A negative value of $\gamma_{3}$ implies that wages rise when unemployment diminishes, so that wages are procyclical. If, on the contrary, $\gamma_{3}$ is positive, wages are countercyclical. As mentioned before, the job finding and the job separation probabilities will also be used as measures of the business cycle. ${ }^{11} 12$

The wage equation is defined in levels in order to be able to estimate the model for workers' hires and separations since, by construction, panel data are not available in these two cases. Thus, whenever necessary to control for worker or firm unobserved heterogeneity the fixed-effects estimator will be used instead of the standard first-differences estimator. This avoids to restrict the sample to solely continuously employed workers. The main problem with this procedure is that workers or firms that appear solely once over the entire period of analysis are excluded. ${ }^{13}$

\section{Empirical Results}

\subsection{Wage Cyclicality of Stayers, Movers, Accessions and Separations}

Equation (1) was estimated by ordinary least squares (OLS) separately for the four groups of workers: stayers, movers, accessions and separations. Besides the aggregate unemployment rate, each regression includes age (and its square) as a proxy for labor market experience, a set of dummies for worker's qualification and education levels and a quadratic time trend. The dependent variable is defined as the natural log of real hourly earnings (HE). The HE corresponds to the ratio of total regular payroll and total number of normal hours. Total regular payroll includes base wages, seniority payments and regular benefits. The wages were deflated using the Consumer Price Index $(\mathrm{CPI})$ and are expressed in 1985 Euros. ${ }^{14}$

Table 2 reports the estimates of the coefficient of the unemployment rate for men and women. Since our data correspond to the whole population of wage earners in the private sector there is no sampling variation and no standard errors are necessary. Thus, standard errors are not reported in the tables of results.

The OLS estimates confirm the empirical stylized fact that real wages changes of movers are much more procyclical than those of stayers. The data also exhibit a strong cyclicality of real wages for accessions and, even more, for separations. According to Table 2, a 1-percentage point decrease in the national unemployment rate raises hourly earnings of men stayers by $1.04 \%$, by $3.32 \%$ for movers, by $1.7 \%$ for newly hired workers and by $2.51 \%$ for recently separated workers. For women these same percentages are, respectively, $0.65,2.28,1.93$ and 2.11 . The less procyclical behavior of women's real wages compared to men's real wages, except for accessions, is in accordance with previous findings shown by Tremblay (1990) and Solon et al. (1994).

\footnotetext{
${ }^{11}$ We thank Olivier Blanchard for this suggestion.

${ }^{12}$ In table A.2 of Appendix A the unemployment rate, the job finding probability and the job separation probability are reported for the 1985-2005 period.

${ }^{13}$ Workers that appear only once over the 1986-2005 period represent roughly $13 \%$ of the total population, whereas the number of firms in this situation is almost negligible.

${ }^{14}$ Between 1986-93 the price index refers to March of year $t-1$ to March of year $t$, whereas from 1994 to 2005 the price index corresponds to October of year $t-1$ to October of year $t$.
} 
Table 2: OLS Results

Dependent variable: log of real hourly earnings (HE)

Portugal, 1986-2005

\begin{tabular}{|l|r|r|r|r|}
\hline \hline & \multicolumn{1}{|c|}{ Stayers } & Movers & Accessions & Separations \\
\hline Men & -1.04 & -3.32 & -1.71 & -2.51 \\
Unemployment Rate & $\mathrm{N}=10.882,682$ & $\mathrm{~N}=1.203,119$ & $\mathrm{~N}=2.410,850$ & $\mathrm{~N}=3.445,218$ \\
& -0.65 & -2.28 & -1.92 & -2.11 \\
Women & $\mathrm{N}=7.005,185$ & $\mathrm{~N}=672,821$ & $\mathrm{~N}=1.606,385$ & $\mathrm{~N}=2.415,541$ \\
\hline
\end{tabular}

Notes: (i) No standard errors were computed since there is no sampling variation.

\subsection{Accounting for Worker and Firm Heterogeneity}

It can always be argued that the heterogeneity in wage responses over the cycle across different groups of workers might be due to unobserved heterogeneity. In this Section the aim is to test if our main qualitative results hold when we account for worker or/and firm unobserved heterogeneity. In particularly, we are interested in comparing the behavior of real wages over the cycle between stayers, accessions and separations.

Hence, in order to account for worker and firm fixed effects we ran equation (1) for the whole population of male and female workers, including dummy variables for hirings and separations and an interaction term between those dummies and the cyclical indicator. Thus, equation (1) becomes:

$$
\begin{aligned}
W_{i j t}= & \alpha_{i}+\alpha_{j}+\gamma_{1} t+\gamma_{2} t^{2}+\gamma_{3} C Y C_{t-1}+\gamma_{4} Z_{i}+\gamma_{5} X_{i t}+\gamma_{6} X_{i t}^{2}+\gamma_{7} \text { Acces }_{t}+ \\
& +\gamma_{8} C Y C_{t-1} \times \text { Acces }_{t}+\gamma_{9} \text { Sep }_{t}+\gamma_{10} C Y C_{t-1} \times S e p_{t}+\varepsilon_{i j t},
\end{aligned}
$$

where $\alpha_{i}$ is an unobserved individual fixed effect and $\alpha_{j}$ a firm-specific effect. Acces is a dummy variable that equals one if worker $i$ is a newly hired worker in period $t$ and Sep is a dummy variable that equals one if worker $i$ separates in period $t+1$.

Table 3 reports the estimates of the unemployment rate coefficient for a fixed effects model that accounts solely for worker unobserved heterogeneity. Comparing with the OLS estimates, controlling for individual unobserved heterogeneity, tends to increase the negative impact of the unemployment rate on wages for stayers and accessions and to decrease for separations. In fact, once worker heterogeneity is taken into account there seems to be no significant difference in cyclicality between stayers and separations. According to Table 3, an unemployment coefficient estimate of 1.53 (-1.19) for male (female) stayers and of -1.31 (-1.11) for male (female) separations was obtained for the model with worker fixed effects.

The estimates of the unemployment rate effect on hourly earnings for job stayers lies between the lower bound for the US of 0.4 obtained by Bils (1985) and the upper bound of 1.93 obtained by Devereux and Hart (2006) for the UK. ${ }^{15}$

\footnotetext{
${ }^{15}$ For a recent summary of these results see Pissarides (2007).
} 
Once again, the results exhibit a greater cyclicality for new hires than for job stayers regardless of the inclusion of worker fixed effects. The magnitudes of the coefficients imply that a one percentage point decrease in the unemployment rate raises hourly earnings of newly hired workers by around $2.3 \%$ for both sexes (see Table 3 ).

These same results hold when we account solely for firm unobserved heterogeneity, even though the difference between stayers and accessions fades (see Table 4). For men, an unemployment coefficient estimate of -1.28 was obtained for stayers against a value of -1.89 for accessions. For women, these same values are, respectively, -0.95 and -1.70 .

Table 3: Worker Fixed Effect Results

Portugal, 1986-2005

\begin{tabular}{|l|r|r|r|}
\hline \hline & Stayers & Accessions & Separations \\
\hline Men (N=14.242,814) & & & \\
Cycle variable: Unemployment Rate & & & \\
Hourly Earnings (HE) & -1.53 & -2.28 & -1.31 \\
Hourly Earnings inc OT (HEIOT) & -1.53 & -2.24 & -1.29 \\
Hourly Base Wage (HBW) & -1.65 & -2.39 & -1.50 \\
Monthly Base Wage (MBW) & -1.95 & -2.54 & -1.88 \\
& & & \\
Women (N=8.126,352) & & & \\
Cycle variable: Unemployment Rate & -1.19 & -2.31 & -1.11 \\
Hourly Earnings (HE) & -1.12 & -2.25 & -1.03 \\
Hourly Earnings inc OT (HEIOT) & -1.46 & -2.47 & -1.42 \\
Hourly Base Wage (HBW) & -1.67 & -2.52 & -1.63 \\
Monthly Base Wage (MBW) & & & \\
\hline \hline
\end{tabular}

Notes: (i) No standard errors were computed since there is no sampling variation. 
Table 4: Firm Fixed Effect Results

Portugal, 1986-2005

\begin{tabular}{|l|r|r|r|}
\hline \hline & Stayers & Accessions & Separations \\
\hline Men (N=14.242,814) & & & \\
Cycle variable: Unemployment Rate & & & \\
Hourly Earnings (HE) & -1.28 & -1.89 & -1.14 \\
Hourly Earnings inc OT (HEIOT) & -1.28 & -1.86 & -1.44 \\
Hourly Base Wage (HBW) & -1.38 & -1.93 & -1.31 \\
Monthly Base Wage (MBW) & -1.68 & -2.09 & -1.76 \\
& & & \\
Women (N=9.322,975) & & & \\
Cycle variable: Unemployment Rate & & & \\
Hourly Earnings (HE) & -0.95 & -1.70 & -0.98 \\
Hourly Earnings inc OT (HEIOT) & -0.94 & -1.69 & -0.95 \\
Hourly Base Wage (HBW) & -1.22 & -1.88 & -1.29 \\
Monthly Base Wage (MBW) & -1.46 & -1.97 & -1.58 \\
\hline \hline
\end{tabular}

Notes: (i) No standard errors were computed since there is no sampling variation.

Finally, equation (2) was re-estimated including both a worker and a firm fixed effect. For this propose an estimation procedure was developed in order to account simultaneously for worker and firm fixed effects. This procedure is described in Appendix B.

The unemployment rate coefficient estimates from the fixed effects model are presented in Table 5. These results corroborate our previous findings. First, once worker and firm heterogeneity are accounted for differences across stayers and separations vanish. Second, entry wages are much more procyclical than current wages. In particular, we found that a 1-percentage point increase in the unemployment rate decreases hourly earnings by $1.45 \%$ for male stayers and by $1.14 \%$ for female stayers. For newly hired workers these same figures are, respectively, $2.49 \%$ and $2.31 \%$.

Table 5: Worker and Firm Fixed Effect Results

Dependent variable: log of real hourly earnings (HE)

Portugal, 1986-2005

\begin{tabular}{|c|r|r|r|}
\hline \hline & Stayers & Accessions & Separations \\
\hline Men (N=14.315,913) & -1.45 & -2.49 & -1.44 \\
Cycle variable: Unemployment Rate & & & \\
Women (N=9.398,893) & & -2.31 & -1.13 \\
Cycle variable: Unemployment Rate & -1.14 & & \\
\hline \hline
\end{tabular}

Notes: (i) No standard errors were computed since there is no sampling variation. 


\subsection{Robustness Checks}

\subsubsection{Alternative Wage Measures}

In order to check if our results are robust to alternative definitions of wages, equation (2) was re-estimated using alternative wage measures. Three other measures of wages were considered: the monthly base wage (MBW), the hourly base wage (HBW) and the hourly earnings including overtime pay (HEIOT). The HBW is defined as the ratio between the monthly base wage and the total number of normal hours worked in the month. The HEIOT is defined as the ratio between total regular payroll including overtime pay and the sum of normal and extra hours of work. As mentioned above, the wages were deflated using the CPI.

The fixed effects results are presented in Tables 6.1 and 6.2 for men and women, respectively. For comparison reasons the unemployment coefficient estimates for HE are reported in the first row.

The inclusion of overtime pay does not change much the estimate of the unemployment rate coefficient for either men and women. This result is not surprising since in the Portuguese labor market overtime hours represent a small percentage of total hours worked.

Comparing the figures obtained for the estimates of the unemployment coefficient using a monthly measure instead of an hourly measure, leads us to conclude that monthly wages are more procyclical than hourly wages, suggesting, as should be expected, that hours worked also exhibit a procyclical pattern.

Table 6.1: Worker and Firm Fixed Effects Results - Men Alternative Wage Measures

Portugal, 1986-2005

\begin{tabular}{|l|c|c|c|}
\hline \hline & Stayers & Accessions & Separations \\
\hline Cycle variable: Unemployment Rate & & & \\
Hourly Earnings (HE) & -1.45 & -2.52 & -1.45 \\
Hourly Earnings inc OT (HEIOT) & -1.45 & -2.49 & -1.44 \\
Hourly Base Wage (HBW) & -1.58 & -2.63 & -1.58 \\
Monthly Base Wage (MBW) & -1.85 & -2.76 & -1.83 \\
\hline \hline
\end{tabular}

Notes: (i) No standard errors were computed since there is no sampling variation.

Table 6.2: Worker and Firm Fixed Effects Results - Women

Alternative Wage Measures

Portugal, 1986-2005

\begin{tabular}{|l|c|c|c|}
\hline \hline & Stayers & Accessions & Separations \\
\hline Cycle variable: Unemployment Rate & & & \\
Hourly Earnings (HE) & -1.14 & -2.31 & -1.13 \\
Hourly Earnings inc OT (HEIOT) & -1.12 & -2.30 & -0.84 \\
Hourly Base Wage (HBW) & -1.42 & -2.54 & -1.21 \\
Monthly Base Wage (MBW) & -1.59 & -2.53 & -1.35 \\
\hline \hline
\end{tabular}

Notes: (i) No standard errors were computed since there is no sampling variation. 


\subsubsection{Disentangling between Job Finding and Job Separation Probabilities}

In this Section the impact of the business cycle on real wages is analyzed using a different cyclical indicator. In particular, equation (2) was re-estimated including the job finding and the job separation probabilities in period $t-1$ as alternative measures to the unemployment rate. The results are shown in Table 7. The coefficients of the new measures have the expected signs: a negative effect on hourly earnings for the job separation probability and a positive one for the job finding probability. Thus, these figures are consistent with the unemployment rate estimates, though their magnitudes cannot be directly compared. Anyway, the results indicate a less pronounced difference in the behavior of real hourly earnings over the cycle across stayers and accessions.

Table 7: Worker and Firm Fixed Effects Results

Dependent variable: log of real hourly earnings (HE)

Portugal, 1986-2005

\begin{tabular}{|l|r|r|r|}
\hline \hline & Stayers & Accessions & Separations \\
\hline Men & -0.103 & -0.143 & -0.131 \\
Cycle variable: Job Separation Probability & 0.513 & 0.629 & 0.546 \\
Women & & & \\
Cycle variable: Job Separation Probability & -0.096 & -0.096 & -0.116 \\
Cycle variable: Job Finding Probability & 0.477 & 0.550 & 0.470 \\
\hline \hline
\end{tabular}

Notes: (i) No standard errors were computed since there is no sampling variation.

\subsection{Bargained Wage, Wage Cushion and the Business Cycle}

In this Section we examine to what extent contractual wages, on the one hand, and firm-specific wage arrangements, in the form of the wage cushion, on the other, are sensitive to the business cycle. Cardoso and Portugal (2005) showed that in Portugal the wage cushion works as a mechanism to overcome the constraints imposed by collective bargaining, granting firms certain freedom when setting wages. In this context, it will be interesting to analyze to what extent contractual wages and firm deviations from contractual wages vary over the business cycle.

The contractual wage was computed adopting the procedure suggested by Cardoso and Portugal (2005). Thus, the BARGW was defined as the mode of the monthly base wage for each worker category within each collective agreement. The wage cushion (WCUSH) was computed as the log difference between the current actual wage and the current contractual wage for that professional category. As exhibited in Tables 8 and 9, the bargained wage is very sensitive to the evolution of the unemployment rate, specially for new hires. The wage cushion, however, exhibits an acyclical behaviour, may be because the wage cushion is used by firma as a mechanism to insure workers from economic shocks. 
Table 8: Worker and Firm Fixed Effects Results Dependent variable: log of real bargained wage (BARGW)

Portugal, 1986-2005

\begin{tabular}{|l|c|c|c|}
\hline \hline & Stayers & Accessions & Separations \\
\hline Men & -1.95 & -2.50 & -1.72 \\
Cycle variable: Unemployment Rate & -0.112 & -0.121 & -0.124 \\
Cycle variable: Job Finding Probability & 0.477 & 0.540 & 0.533 \\
$\begin{array}{l}\text { Women } \\
\text { Cycle variable: Unemployment Rate }\end{array}$ & -1.83 & -2.35 & -1.59 \\
\hline \hline
\end{tabular}

Notes: (i) No standard errors were computed since there is no sampling variation. 
Table 9: Worker and Firm Fixed Effects Results

Dependent variable: wage cushion (WCUSH)

Portugal, 1986-2005

\begin{tabular}{|l|c|c|c|}
\hline \hline & Stayers & Accessions & Separations \\
\hline Men & -0.002 & -0.006 & -0.002 \\
Cycle variable: Job Separation Probability & 0.013 & -0.020 & -0.012 \\
Cycle variable: Job Finding Probability & 0.000 & 0.026 & 0.006 \\
$\begin{array}{l}\text { Women } \\
\text { Cycle variable: Unemployment Rate }\end{array}$ & 0.139 & -0.224 & 0.095 \\
\hline \hline
\end{tabular}

Notes: (i) No standard errors were computed since there is no sampling variation.

\section{Conclusion}

The aim of this study is to provide further evidence on real wage cyclicality using a rich longitudinal matched employer-employee dataset for the 1986-2005 period, addressing the issue of heterogeneity in wages responses to aggregate labor market conditions, across different groups of workers: stayers, accessions, and separations. For this purpose, we employ information on the registry of all Portuguese wage earners in the private sector comprising around 25 million worker-year observations.

The main contribution of this paper is to analyze the impact of the business cycle on real wages accounting simultaneously for worker and firm permanent unobserved heterogeneity. To achieve this objective, we employ a new iterative procedure which provides the exact OLS solution to the two-way fixed effect model. To the best of our knowledge, previous empirical research on the wage cyclicality never consider the role of firm heterogeneity, restricting the attention solely to the compositional bias generated by the presence of worker unobserved heterogeneity.

The empirical evidence gathered in this exercise is fourfold. First, accounting for both worker and firm heterogeneity, there is an indication of a moderate procyclical behaviour of real wages for job stayers. The unemployment rate semi-elasticities estimates are in the order of -1.1 for females to $-1.5 \%$ for males. That is, among workers in continuing jobs, an increase of a percentage point in the unemployment rate leads real wage decline between 1.1 and 1.5 percent. Identical estimates were obtained for recently separated workers.

Second, wages of recently hired workers are much more procyclical than the wages of continuing employed workers. A one-point increase in the unemployment rate decreases real wages of newly hired workers by around 2.5 percent for men, and 2.3 percent for women. These results are robust to changes in the definition of hourly earnings.

Third, when we employ alternative measures of the business cycle, that is, when we use the job finding probability and the job separation probability instead of the unemployment rate, we again found support for the cyclicality of real wages. In those specifications, however, the distinction between new hires and stayers is less sharp, most notably, for the measure of job finding probability. 
Fourth, because firms often pay wages above the wage floors negotiated between the employer associations and the trade unions, we decompose the observed wage between the bargained wage component - that agreed at the bargaining table - and the wage cushion component - that obtained from the difference between the actual wage and the bargained wage. We found that the bargained wage is very sensitive to the evolution of the unemployment rate, whereas the wage cushion exhibits an acyclical behaviour.

\section{References}

[1] Abraham, K. and J. Haltiwanger (1995), "Real Wages and the Business Cycle", Journal of Economic Literature, Vol. 33, pp. 1215-1264.

[2] Barlevy, G. (2001), "Why Are the Wages of Job Changers So Procyclical?", Journal of Labor Economics, Vol. 19, pp. 837-878.

[3] Beaudry, P. and J. DiNardo (1991), "The Effect of Implicit Contracts on the Movement of Wages over the Business Cycle: Evidence from Micro Data", Journal of Political Economy, Vol. 99 , pp. 665-688.

[4] Bils, M. (1985), "Real Wages over the Business Cycle: Evidence from Panel Data", Journal of Political Economy, Vol. 93, pp. 666-689.

[5] Brandolini, A. (1995), "In Search of a Stylised Fact: Do Real Wages Exhibit a Consistent Pattern of Cyclical Variability?", Journal of Economic Surveys, Vol. 9, pp. 103-163.

[6] Cardoso, A. and P. Portugal (2005), "Contractual Wages and the Wage Cushion under Different Bargaining Settings", Journal of Labor Economics, Vol. 23, pp. 503-523.

[7] Devereux, P. (2001), "The Cyclicality of Real Wages within Employer-Employee Matches", Industrial and Labor Relations Review, Vol. 54, pp. 835-850.

[8] Devereux, P. and R. Hart (2006), "Real Wage Cyclicality of Job Stayers, Within-Company Job Movers, and Between- Company Job Movers", Industrial and Labor Relations Review, Vol. 60, pp. 105-119.

[9] Dunlop, J. (1938), "The Measurement of Real Wages and Money Wage Rates", Economic Journal, Vol. 48, pp. 413-434.

[10] Hall, R. (2003), "Modern Theory of Unemployment Fluctuations: Empirics and Policy Applications", American Economic Review Papers and Proceedings, Vol. 93, pp. 145-150.

[11] Hall, R. (2005), "Employment Fluctuations with Equilibrium Wage Stickiness", American Economic Review, Vol. 95, pp. 50-65.

[12] Hart, R. (2006), "Worker-Job Matches, Job Mobility and Real Wage Cyclicality", Economica, Vol. 73 , pp. 287-298.

[13] Keane, M., R. Moffitt and D. Runkle (1988), "Real Wages over the Business Cycle: Estimating the Impact of Heterogeneity with Micro Data", Journal of Political Economy, Vol. 96, pp. 12361266. 
[14] Keynes, J. (1939), "Relative Movements of Real Wages and Output", Economic Journal, Vol. 49 , pp. $34-51$.

[15] Mitchell, M., M. Wallace and J. Warner (1985), "Real Wages over the Business Cycle: Some Further Evidence", Southern Economic Journal, Vol. 51, pp. 1162-1173.

[16] Mortensen, D. and C. Pissarides (1994), "Job Creation and Job Destruction in the Theory of Unemployment", Review of Economic Studies, Vol. 61, pp. 397-415.

[17] Okun (1973), "Upward Mobility in a High-pressure Economy", Brookings Papers on Economic Activity, Vol. 1, pp. 207-252.

[18] Pissarides, C. (2000), Equilibrium Unemployment Theory, 2nd. Ed., Cambridge, MA, MIT Press.

[19] Shimer, R. (2004), "The Consequences of Rigid Wages in Search Models", Journal of the European Economic Association, Vol. 2, pp.469-479.

[20] Shimer, R. (2005), "The Cyclical Behavior of Equilibrium Unemployment and Vacancies", American Economic Review, Vol. 95, pp. 25-49.

[21] Shin, D. (1994), "Cyclicality of Real Wages among Young Men", Economics Letters, Vol. 46, pp. 137-142.

[22] Solon, G., R. Barsky and J. Parker (1994), "Measuring the Cyclicality of Real Wages: How Important is Composition Bias?", Quarterly Journal of Economics, Vol. 109, pp. 1-25.

[23] Tremblay, C. (1990), "Wage Patterns of Women over the Business Cycle", Quarterly Review of Economics and Business, Vol. 30, pp. 90-101. 
APPENDIX A - Descriptive Statistics

Table A.1.1: Descriptive Statistics (1986-2005)

Men $(\mathrm{N}=14.315,913)$

\begin{tabular}{|l|r|r|r|r|}
\hline \hline & MEAN & STDV & MIN & MAX \\
\hline Variables & & & & \\
Age (in years) & 36.4 & 9.7 & 20.0 & 56.0 \\
Education (in years) & 7.0 & 3.7 & 0.0 & 16.0 \\
Qualification Level & & & & \\
Top Executives & 0.046 & & 0.0 & 1.0 \\
Intermediary Executives & 0.034 & & 0.0 & 1.0 \\
Supervisors & 0.057 & & 0.0 & 1.0 \\
Highly Skilled and Skilled Professionals & 0.569 & & 0.0 & 1.0 \\
Semi-skilled and Unskilled Professionals & 0.221 & & 0.0 & 1.0 \\
Apprentices & 0.041 & & 0.0 & 1.0 \\
Non-defined & 0.032 & & 0.0 & 1.0 \\
Monthly Base Wage (MBW in real euros) & 536.3 & 381.5 & 50.7 & 4061.0 \\
Hourly Base Wage (HBW in real euros) & 3.2 & 2.38 & 0.4 & 23.2 \\
Hourly Earnings (HE in real euros) & 3.8 & 3.14 & 0.4 & 194.0 \\
Hourly Earnings inc OT (HEIOT in real euros) & 3.8 & 3.16 & 0.4 & 194.0 \\
\hline \hline
\end{tabular}

Table A.1.2: Descriptive Statistics (1986-2005)

Women $(\mathrm{N}=9.398,893)$

\begin{tabular}{|l|r|r|r|r|}
\hline \hline & MEAN & STDV & MIN & MAX \\
\hline Variables & & & & \\
Age (in years) & 34.4 & 9.1 & 20.0 & 56.0 \\
Education (in years) & 7.6 & 3.9 & 0.0 & 16.0 \\
Qualification Level & & & & \\
Top Executives & 0.032 & & 0.0 & 1.0 \\
Intermediary Executives & 0.027 & & 0.0 & 1.0 \\
Supervisors & 0.024 & & 0.0 & 1.0 \\
Highly Skilled and Skilled Professionals & 0.472 & & 0.0 & 1.0 \\
Semi-skilled and Unskilled Professionals & 0.351 & & 0.0 & 1.0 \\
Apprentices & 0.069 & & 0.0 & 1.0 \\
Monthly Base Wage (MBW in real euros) & 456.2 & 324.4 & 50.4 & 4050.0 \\
Hourly Base Wage (HBW in real euros) & 2.74 & 2.11 & 0.35 & 23.2 \\
Hourly Earnings (HE in real euros) & 3.11 & 2.61 & 0.35 & 118.6 \\
Hourly Earnings inc OT (HEIOT in real euros) & 3.12 & 2.62 & 0.35 & 118.6 \\
\hline \hline
\end{tabular}


Table A.2: Unemployment Rate, Job Finding

Probability and Job Separation Probability

Portugal, 1985-2005

\begin{tabular}{|c|c|c|c|}
\hline \hline & $\begin{array}{c}\text { Unemployment } \\
\text { Rate }(\%)\end{array}$ & $\begin{array}{c}\text { Job Finding } \\
\text { Probability (\%) }\end{array}$ & $\begin{array}{c}\text { Job Separation } \\
\text { Probability (\%) }\end{array}$ \\
\hline 1985 & 7.2 & 12.4 & 1.35 \\
1986 & 7.4 & 17.4 & 1.41 \\
1987 & 6.5 & 21.1 & 1.30 \\
1988 & 5.7 & 20.3 & 1.16 \\
1989 & 4.5 & 20.0 & 1.14 \\
1990 & 5.1 & 25.7 & 1.24 \\
1991 & 4.7 & 26.4 & 1.16 \\
1992 & 3.9 & 21.1 & 1.26 \\
1993 & 5.0 & 15 & 1.40 \\
1994 & 6.0 & 17.5 & 1.59 \\
1995 & 6.2 & 15.4 & 1.30 \\
1996 & 6.3 & 15.1 & 1.23 \\
1997 & 5.9 & 21.5 & 1.37 \\
1998 & 5.0 & 26.2 & 1.26 \\
1999 & 4.4 & 25.1 & 1.24 \\
2000 & 3.9 & 24.4 & 1.11 \\
2001 & 4.0 & 25.7 & 1.35 \\
2002 & 5.0 & 19.5 & 1.71 \\
2003 & 6.3 & 21.6 & 1.67 \\
2004 & 6.8 & 15.8 & 1.56 \\
2005 & 7.6 & 16.7 & 1.57 \\
\hline \hline
\end{tabular}

Source: Bank of Portugal and Franco and Torres(2008). 
APPENDIX B - Worker and Firm Fixed Effects: Estimation Technique 
In this appendix we detail our estimation technique for the model that includes both firm and worker fixed effects. Because of the high dimensionality of the problem adding actual dummy variables to account for any of the fixed effects is not a feasible approach. However, as it turns out, application of a partitioned algorithm greatly simplifies the estimation problem at hand and leads to the full least squares solution. The idea consists of estimating the model by cycling between estimation on subsets of the parameters [for a discussion of partitioned algorithms see, for example, Smyth, G. (1996)]. To see how this applies to our problem consider the simplest case of the typical least squares dummy variable model

$$
\mathbf{Y}=\mathbf{X} \boldsymbol{\beta}+\mathbf{D} \boldsymbol{\alpha}+\varepsilon,
$$

where $\mathbf{X}$ is an $M \times k$ matrix of regressors, $\mathbf{D}$ is an $M \times n$ matrix containing $n$ dummy variables that account for group membership and $\boldsymbol{\beta}$ and $\boldsymbol{\alpha}$ are the unknown parameters. If the least squares solution for the $\boldsymbol{\alpha}$ were known then we could obtain the least squares estimates of $\boldsymbol{\beta}$ by regressing $\mathbf{Y}$ on $\mathbf{X}$ and an additional single variable containing the estimates of the $\alpha s$. On the other hand, if the least squares solution for $\boldsymbol{\beta}$ were known we could easily obtain least squares estimates for the $\boldsymbol{\alpha}$. The normal equations show that these are simply the group means of the elements of the vector $\mathbf{u}=\mathbf{Y}-\mathbf{X} \widehat{\boldsymbol{\beta}}$. Hence, an estimation procedure for $\boldsymbol{\beta}$ and $\boldsymbol{\alpha}$ could be implemented as follows:

1) Obtain initial values for $\boldsymbol{\beta}$ by regressing $\mathbf{Y}$ on $\mathbf{X}$;

2) Compute $\mathbf{u}$ using the latest estimates of $\boldsymbol{\beta}$;

3) Calculate estimates of $\boldsymbol{\alpha}$ as the group means of the elements of $\mathbf{u}$;

4) Estimate $\boldsymbol{\beta}$ by regressing $\mathbf{Y}$ on $\mathbf{X}$ and an additional variable containing the last estimates of the $\boldsymbol{\alpha}$;

5) Return to step 2 until convergence.

Notice that computationally all that is required is the estimation of several least squares regressions with $k+1$ explanatory variables and group means of elements of $\mathbf{u}$. As is well known a better approach to estimate $\boldsymbol{\beta}$ consists on running a regression in terms of deviations from group means (the within-groups estimator). Consider now the case when a second fixed effect is added to (1),

$$
\mathbf{Y}=\mathbf{X} \boldsymbol{\beta}+\mathbf{D} \boldsymbol{\alpha}+\mathbf{G} \boldsymbol{\gamma}+\boldsymbol{\varepsilon}
$$

where $\mathbf{G}$ is a matrix of dimension $M \times p$ containing $p$ columns indicating membership to the second group and $\gamma$ is a vector of parameters. Now, the withingroups estimator is no longer a viable alternative. However, the partition algorithm detailed above can be easily modified to accomodate this more complex case. In this case one iterates between estimation of $\boldsymbol{\beta}, \boldsymbol{\alpha}$ and $\boldsymbol{\gamma}$. To estimate $\boldsymbol{\beta}$ in each iteration we regress $\mathbf{Y}$ on $\mathbf{X}$ and two additional variables, containing the last available estimates of $\boldsymbol{\alpha}$ and $\boldsymbol{\gamma}$. In each step we obtain estimates for $\boldsymbol{\alpha}$ by computing the group means of $\mathbf{u}_{1}=\mathbf{Y}-\mathbf{X} \widehat{\boldsymbol{\beta}}-\widehat{\boldsymbol{\gamma}}$ and the estimates for $\gamma$ are computed in a similar way. Thus, the full least squares equation may be estimated by iteratively running a linear regression with only $k+2$ regressors and computing group means. A well known disadvantage of partitioned algorithms is their slow rate of convergence. To accelerate convergence of the model 
with two fixed effects we adopt two strategies. First, we eliminate the need to estimate the second fixed effect in each iteration by using the within-groups estimator. This amounts to replacing the linear regression in step 4) of the algorithm by a regression with deviations from the means of the second group. Second, in each iteration we retain the last two estimates of $\boldsymbol{\alpha}$ and use the three data points to adjust the trajectory of the estimates for the fixed effects. The estimation routines are implemented in Stata and are publicly available in the Statistical Software Components (SSC) archive. ???

Reference:

Gordon K. Smyth, (1996) Partitioned Algorithms for Maximum Likelihood and other non-linear Estimation. Statistics and Computing. vol 6, pp. 201-216. 